\title{
New and in North Europe rare polypore species (Basidiomycota) with annual, monomitic basidliocarps
}

\author{
TUOMO NIEMELÄ, YU-CHENG DAI, JUHA KINNUNEN and DMITRY S. SCHIGEL
}

\begin{abstract}
Niemelä, T., Dai, Y.C., Kinnunen, J. \& Schigel, D.S. 2004: New and in North Europe rare polypore species (Basidiomycota) with annual, monomitic basidiocarps. - Karstenia 44: 67-77. 2004. Helsinki. ISSN 0453-3402.

Two new species of polypores are described: Postia balsamina Niemelä \& Y.C. Dai and P. persicina Niemelä \& Y.C. Dai. They were collected on Picea abies in Northern boreal zone. Postia balsamina is white, fleshy and almost resupinate, monomitic, and bears rather thin-walled, acute cystidia with minute apical encrustation; cystidia are usually found in hymenium close to tube orifices and their amount increases by age. The species is reported from northern Finland and Sweden. It resembles $P$. balsamea (Peck) Jülich, which is pileate, more tough, with smaller spores and pores; P. balsamea occurs as rare in South Finland, and its distribution in Europe is southerly. P. persicina is beautifully orange-red, pileate, and its white pore surface turns yellow when drying. Externally it resembles Tyromyces kmetii (Bres.) Bondartsev \& Singer, which grows on angiosperm trees and whose spores are much thicker. In addition to Finland, it was found once in Russian Karelia, growing on spruce. P. luteocaesia (A. David) Jülich is reported from Finland. It is compared to the closest related species, $P$. caesia (Fr.) P. Karst., P. subcaesia (A. David) Jülich, P. alni Niemelä \& Vampola and its brief description is included.
\end{abstract}

Key words: Basidiomycota, Postia balsamea, Postia balsamina, Postia luteocaesia, Postia persicina, polypore, taxonomy

Tuomo Niemelä, Juha Kinnunen and Dmitry S. Schigel, Finnish Museum of Natural History, Botanical Museum, P.O. Box 7, FI-00014 University of Helsinki, Finland

Yu-Cheng Dai, Institute of Applied Ecology, Chinese Academy of Sciences, Wenhua Road 72, Shenyang 110016, China

\section{Introduction}

In 1999 the governmental Metsähallitus (Finnish Forest and Park Service) set up a four-year project Conservation of the Ylläs-Aakenus Western Taiga Forest Area in Lapland with the support from the European Union financed LIFE Nature Fund. Forests and wetlands of the Ylläs-Aakenus area in northern Finland were studied in order to get information on species diversity there. Vascular plants, mosses, polypores, lichens, birds, fishes and insects were inventoried. The results offered basic information for management planning of the area. The work was organized by the Natural Heritage Services, and its first results were reported in Koivisto (2003).

Polypores and other wood-inhabiting fungi of the area were studied during three subsequent years. The work was started in 1999 by the authors YCD and TN, and completed in 2000 and 2001 by the latter together with JK and DSS. Some other biologists took part in the fieldwork, and in most of the inventory days a person from the Natural Heritage Services accompanied us.

The basic reason for making the inventories was that the 386.5 square kilometre Ylläs-Aake- 
nus region, including protected forests and peatlands, was intended to become a future national park. The decision has now been made to merge the Ylläs-Aakenus region with the Ounas-Pallastunturi National Park further north. Altogether this will make the third largest continuous nature reserve in Finland, totalling ca. 1000 square kilometres, and extending ca. 100 kilometres in the north-south direction. The new entity will be named the Ylläs-Pallas National Park, after its two well-known peaks.

The Ylläs-Aakenus area comprises spruce and pine dominated forests of Northern boreal zone, not far from northern timberline. Montane forest line is reached in the area at the altitude of 420 480 metres (Pyhätunturi and Äkäskero), but this is not necessarily climatic limit because the hilltops are barren, stony outcrops. The highest peaks are 613 (Lainiotunturi) and 718 (Y1läs) metres a.s.l. This is an area of ancient, low-stature mountains (fells) and lower hills of granitic bedrock rich in quarzite, mostly being exposed as a result of repeated glaciations during the Ice Ages of the Quaternary. In the area there are barren stony hilltops, forested lower slopes, gorges with herb-rich vegetation, peatlands, and several lakes and watercourses. Human population has always been very sparse, and traditionally reindeer-herding.

About $80 \%$ of the forests in the area exceed 160 years' age. Most of these forests have never been cut down, although selective loggings (mostly of old pine, in particular kelo; see Niemelä et al. 2002) have been performed extensively. Because of the high age of the forests, we had expectations of finding a great deal of species characterizing oldgrowth forests there. In addition to several rarities, also species new to science were found, for instance one hydnaceous stipitate fungus (Niemelä et al. 2003) and two polypores dealt with here.

The other area of our study, Repovesi National Park, is situated in Valkeala and Mäntyharju communes of Central Finland, Etelä-Savo province. Mostly this is state-owned land but it includes the Aarnikotka Reserve owned and protected by the UPM-Kymmene paper company. Botanically it belongs to the Southern Boreal zone which is characterized by dense spruce- and pinedominated forests. It totals an area of ca. 30 square kilometres, including (or touching) over 90 lakes of various sizes (mostly small), and hilly terrain with pine-wooded rock outcrops, steep slopes, spruce-dominated valleys and gorges, and a few small peatlands. Water-level is elevated by beavers in many of the smaller lakes, resulting in an abundance of dead trees along lakesides. Most forests are fairly young in this recently (in 2003) established national park. Three of us (TN, JK, DSS) inventoried the polypores of the area in 2004. One of the species reported in this paper was found in the Repovesi National Park.

\section{Materials and methods}

Specimens were mostly collected by the authors with coworkers. They were photographed in the field, and fresh character and ecology notes were made. Specimens were dried soon after field trips in a mushroom dryer with ventilated $30-40^{\circ} \mathrm{C}$ temperature.

In addition to the new species, selected voucher materials of related species were studied for comparison. All the specimens listed are deposited in the Botanical $\mathrm{Mu}$ seum of the University of Helsinki $(\mathrm{H})$, unless otherwise indicated. Herbarium names are abbreviated according to Holmgren et al. (1990).

Postia balsamea (Peck) Jülich and P. luteocaesia (A. David) Jülich have been well described in many manuals (e.g. Ryvarden \& Gilbertson 1993-1994), and we make here just brief descriptions on the basis of new collections.

Microscopic studies were done and spores were measured from sections mounted in Cotton Blue (abbreviated $\mathrm{CB}$ ): $0.1 \mathrm{mg}$ aniline blue (Merck 1275) dissolved in $60 \mathrm{~g}$ pure lactic acid; $\mathrm{CB}+$ means cyanophily, $\mathrm{CB}(+)$ weak but distinct cyanophilous reaction, $\mathrm{CB}-$ acyanophily. Amyloid and dextrinoid reactions were tested in Melzer's reagent (IKI): $1.5 \mathrm{~g} \mathrm{KI}$ (potassium iodide), $0.5 \mathrm{~g} \mathrm{I}$ (crystalline iodine), $22 \mathrm{~g}$ chloral hydrate, aq. dest. $20 \mathrm{ml}$; IKImeans neither amyloid nor dextrinoid reaction. Occasionally also $5 \% \mathrm{KOH}$ was used as mountant or reagent.

As a rule 30 spores were measured from each specimen selected for closer scrutiny. Measurements were done using $\times 1250$ magnification, phase contrast and oil immersion; eyepiece scale bar showed a $1-\mu \mathrm{m}$-grid, and dimensions were estimated subjectively with an accuracy of $0.1 \mu \mathrm{m}$. In presenting the variation of spore size, $5 \%$ of the measurements out of each end of the range are given in parentheses. $\mathrm{L}=$ mean length (arithmetical mean of all spores), $\mathrm{W}=$ mean width, $Q=$ extreme values of the length/width ratios among the studied specimens, and $n=$ the number of spores measured from given number of specimens.

The main reference books used were: Bondartsev (1953), Gilbertson \& Ryvarden (1986-1987), Ryvarden \& Gilbertson (1993-1994), Núñez \& Ryvarden (2001), and Hansen \& Knudsen (1997). Special colour terms are from Anonymous (1969), Rayner (1970) and Petersen (1996).

$\begin{aligned} & \text { Postia balsamina Niemelä \& Y.C. Dai, } \\ & \text { species nova }\end{aligned}$
Figs. 1,2

Carpophorum annuum, resupinatum vel effusoreflexum, molle, colore album vel in statu sicco brunneo-cremeum; systema hypharum monom- 
iticum, hyphae fibulatae; cystidiae lanceolatae vel fusiformae; sporae angusto-ellipsoideae, $4.3-5.6 \times 2.3-2.9 \mu \mathrm{m}$.

Holotype: Finland. Kittilän Lappi. Kolari, Äkäslompolo, north of Kesänkijärvi, Picea abies, fallen trunk, 31.VIII.1999 Tuomo Niemelä 6601 \& YuCheng Dai $(\mathrm{H})$.

Etymology: balsamina (Lat., adj.), referring to microscopic similarity with Postia balsamea.

Basidiocarp annual, resupinate or effused-reflexed with minute pilei (1-2 cm wide, projecting $0.5-1 \mathrm{~cm}$ ) bordering a wide resupinate part, up to $20 \times 7 \mathrm{~cm}$, when young fleshy and juicy, soft to touch but flexible and cartilaginous if torn apart, when dry soft corky and easy to cut. Upper surface soft matt or somewhat floccose, uniformly white and azonate; in old and dry specimens cream coloured. Pore surface white when fresh and young, older parts attaining a faint ochraceous or salmon tint, when dry sordid brownish cream (buff, pale olivaceous buff); craters of guttation droplets sometimes frequent; pores angular, (1-)3-4(-5) per mm; sterile margin bordering resupinate areas usually wide $(1-5 \mathrm{~mm})$, fibrous, when fresh white, when dry cream coloured. Section: subiculum thick (1-2 mm), cartilaginous and translucent when fresh, opaque white and tough corky when dry; fresh tubes white, dry creamcoloured or brownish, concolorous with pore surface. No specific smell or faint fungoid smell; taste mild.

Monomitic, hyphae hyaline, with clamp connections, amyloid (IKI grey to pink; amyloidy most distinct in subiculum close to tube bottoms), CB-, almost unchanged in $\mathrm{KOH}$. Subiculum hyphae (3-)3.7-5.3(-5.5) $\mu \mathrm{m}$ in diam., thick-walled to sclerified (wall up to $1.5 \mu \mathrm{m}$ ), interwoven with radial orientation, in a fairly tight texture but not glued together. Tube trama with faintly amyloid hyphae, $2.9-4(-4.2) \mu \mathrm{m}$, fairly thin-walled at orifices but thick-walled and glued-together higher up, subparallel; subhymenium thin and indistinct. Hymenium with clavate basidia $15-17(-23) \times 5.3-6$ $\mu \mathrm{m}$, short clavate basidioles $10-16 \times 4.5-5.8 \mu \mathrm{m}$; cystidioles with short finger-like apex, becoming commoner towards the end of the season; cystidia common or abundant but in young basidiocarps found only locally close to tube orifices, (13-)15$25(-28) \times(4-) 4.8-6.5(-8) \mu \mathrm{m}, \mathrm{L}=20.36 \mu \mathrm{m}, \mathrm{W}=5.50$

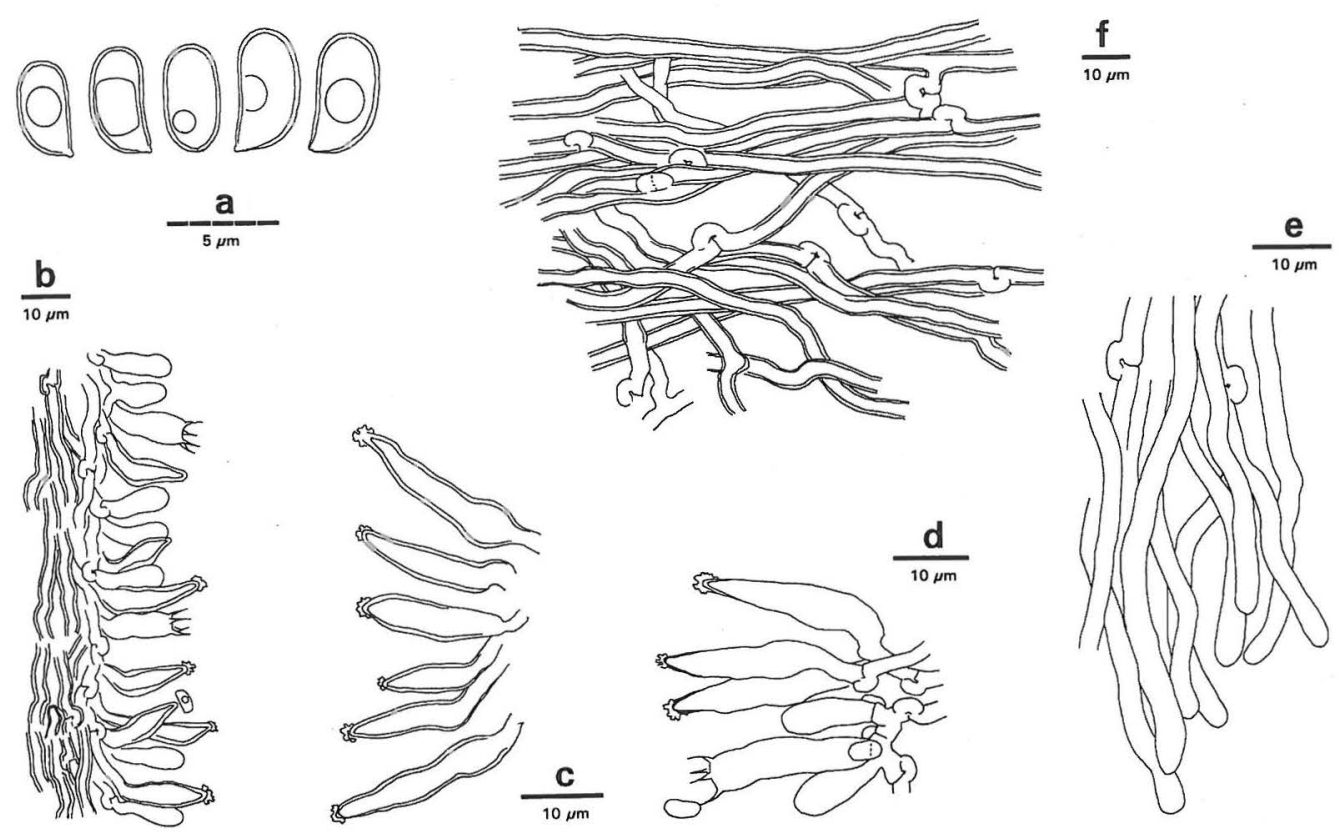

Fig. 1. Postia balsamina Niemelä \& Y.C. Dai. - a) Spores, b) vertical section through hymenium showing basidia, basidioles and cystidia, c) mature cystidia, d) hymenial cells with juvenile cystidia, e) hyphae from dissepiment edge, f) subicular hyphae. Drawn in CB from Niemelä 6769 (b, c) and holotype (the others). 
$\mu \mathrm{m}, \mathrm{Q}=3.25-5.09(\mathrm{n}=58 / 5)$, conical, obclavate, lanceolate or fusiform, mostly terminal but also pleural cystidia common, with wall slightly thicker than in basidia and basidioles (young specimens) or strongly thickened (old), and acute tip mostly rough because of minute crystal sand. Hyphal tips normal at dissepiment edge.

Spores ellipsoid or narrow ellipsoid, thinwalled, IKI-, CB-, (4.1-)4.3-5.6(-6.9) $\times(2.2-) 2.3-$ 2.9(-3.1) $\mu \mathrm{m}, \mathrm{L}=4.87 \mu \mathrm{m}, \mathrm{W}=2.62 \mu \mathrm{m}, \mathrm{Q}=1.83-1.92$ $(\mathrm{n}=150 / 5)$.

Specimens examined: Finland. Perä-Pohjanmaa. Rovaniemi rural comm., Pisavaara Strict Nat. Res., Kuusilaki, Picea abies, 31.VIII.1960 Kujala \& Eriksson 9696 (ex GB 4155); 6.IX.2003 Kinnunen 2168. Kittilän Lappi. Kittilä, in valley between Mustakero and Kulkukero, P. abies, 24.VIII.2000 Niemelä 6769 \& Kinnunen. Kolari, Äkäslompolo, Kesänkijärvi N slope, P. abies, 20.VIII.1999 Niemelä 6490 \& Dai, 29.VIII.1999 Niemelä 6576 \& Dai, 31.VIII.1999 Niemelä 6601 \& Dai (holotype); Varkaankuru, P. abies, 15.VIII.2000 Niemelä 6679. Sompion Lappi. Savukoski, Maaselkä 13 km NW of Savukoski church village, P. abies, VIII.1994 Hiltunen 2292. Sweden. Lule Lappmark. Gällivare, Granlandet, P. abies, 21.IX.1993 Bader \& Norstedt 32.

\section{Notes on Postia balsamina}

The species will key out as Postia balsamea (Oligoporus balsameus (Peck) Gilb. \& Ryvarden), if identified with the aid of recent manuals, because in the microscope the two species share a monomitic structure, subulate cystidia, and ellipsoid spores. However, P. balsamina has longer spores and larger pores (albeit measurements overlap), and its cystidia seem to be more distinctly projecting, more sharp-pointed and more regularly encrusted. The amyloidy of the hyphae is stronger and more regular than in P. balsamea.

Macroscopically the new species bears little resemblance to $P$. balsamea; the white, rubbery flexible, juicy basidiocarp looks more like an exceptionally large and luxuriant specimen of Postia undosa (Peck) Jülich. The more distinctly pileate and corky tough $P$. balsamea resembles some Trametes species, Antrodiella semisupina (Berk. \& M.A. Curtis) Ryvarden, or A. fragrans (A. David \& Tortić) A. David \& Tortić).

Postia balsamina resembles young, almost resupinate Climacocystis borealis: both they grow on coniferous trees, and are monomitic with similar cystidia and spore shape. The latter is finally pileate, tough and strongly fibrous, and its pores are larger and often sinuous; it is a white-rot fungus. Postia balsamina may produce pilei, but they develop as small projections bordering the wide resupinate part only, and usually the whole basidiocarp is resupinate. It feels fibrous, too, if torn apart when fresh, but in a softer and more fleshy way. The pores of $P$. balsamina are fairly regularly angular.

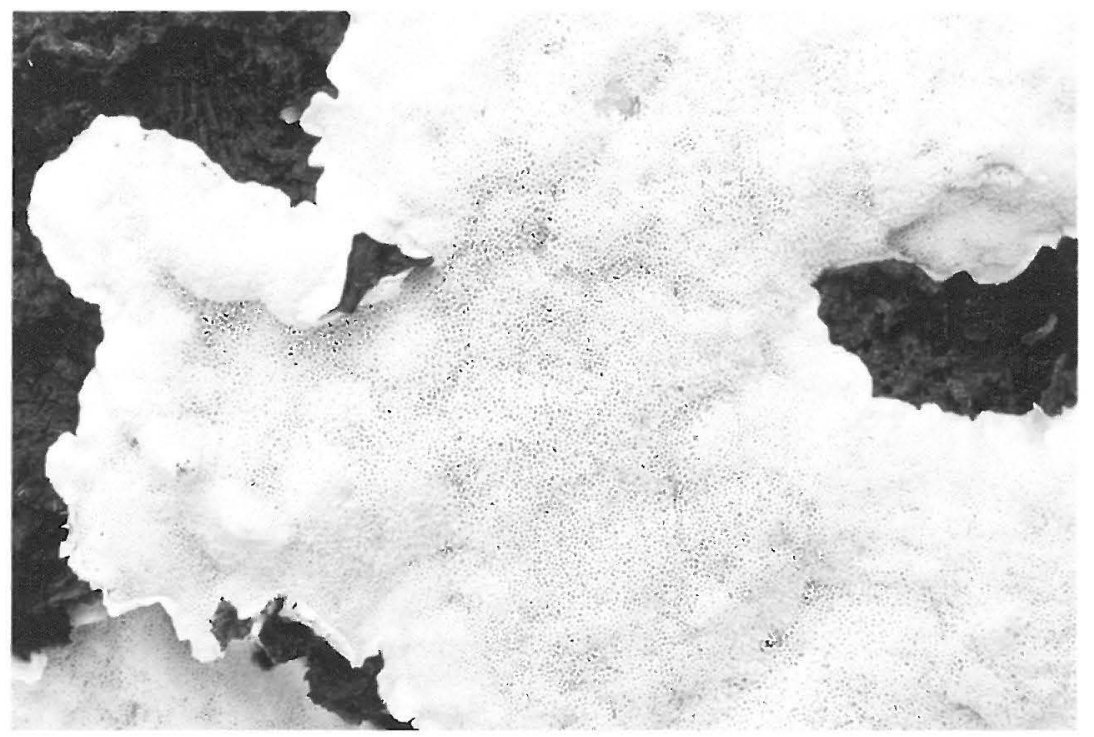

Fig. 2. Postia balsamina Niemelä \& Y.C. Dai. Holotype, photographed in situ. Magnification ca. $\times 1.6$ 
There was some controversy on the decay type caused by Postia balsamina. While most basidiocarps were growing on soft, widespread white-rot, one (6769) was collected from brownrotted wood. There had evidently been other fungi growing on the trunk before, and the decay caused by this species could not be easily seen. In some tree trunks there were remnants of dead Trichaptum, and our new species may be its successor. Dr Kari Steffen (pers. comm.) kindly isolated a culture from our collection and confirmed that $P$. balsamina is a brown-rot fungus.

Resupinate, young basidiocarps of $P$. balsamina may be confused with Oligoporus sericeomollis (Romell) M. Bondartseva, because the two have monomitic structure with fairly thick-walled and clamped hyphae, spores are fairly similar (strongly cyanophilous in $O$. sericeomollis), and they both have cystidia. However, in $O$. sericeomollis the cystidia are heavily encrusted, and less conical in their shape. Eventually P. balsamina is a thicker and more robust species.

Postia balsamina was collected on fallen, thick, still corticated trunks of Picea abies subsp. obovata in virgin spruce swamps or otherwise humid habitats. In most cases the large fruit body was situated on the lower side of the trunk, very close to mossy ground, and it took quite an effort to turn the trunks around. Evidently a tight ground contact of the trunk is needed to keep the sub- strate moist enough throughout the season. Our collections from Finland and Sweden imply that this is a northern fungus of old-growth spruce forests: the collections derive from Northern Boreal zone and its transition to Middle Boreal (Pisavaara). Some more southern (Middle or South Boreal) old forests in Ilomantsi (Koitajoki Nature Reserve, 2002-2003: Schigel et al. 2004), Valkeala (Repovesi National Park, 2004), Eno (Kolvananuuro and Kirjovaara, 2004) and elsewhere were intensively inventoried with the same field methods, and this species was not found. Obviously this is a rare thing.

In the discussion of Tyromyces kymatodes (Rostk.) Bondartsev \& Sing. (= Postia balsamea) Bondartsev (1953: 218) mentions a collection from Kamenets-Podol'skiy, a resupinate, white basidiocarp which 'we might have described ... as a separate variety'; this may refer to Postia balsamina.

Niemelä (2001a, b, 2004) tentatively introduced the species as Postia balsamina nom. prov. in Finnish and Russian articles.

\section{Postia balsamea (Peck) Jülich Figs.3,4}

Polyporus balsameus Peck, New York State Mus. Nat. Hist. Ann. Rep. 30: 46, 1878. Holotype: 'Adirondack Mts., on spruce, C.H. Peck', NYS (studied). - Oligoporus balsameus (Peck) Gilb. \& Ry-
Fig. 3. Postia balsamea (Peck) Jülich, growing on living Crataegus douglasii. Specimen Niemelä $6876, \times 0.8$.

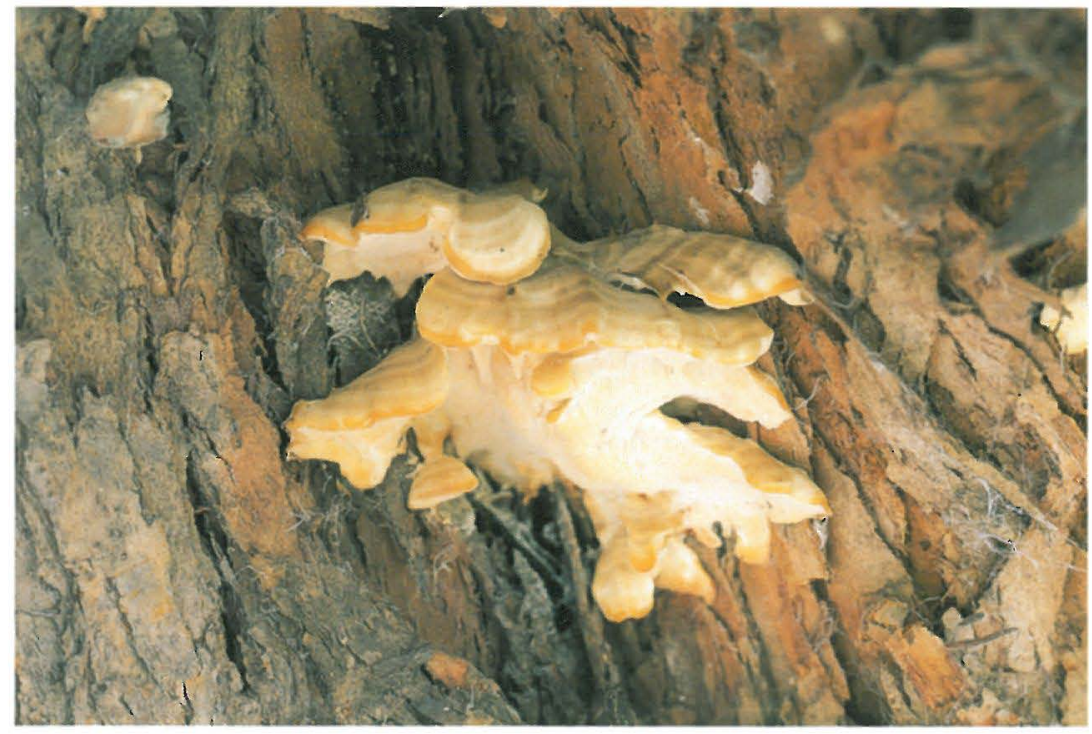


varden, Mycotaxon 22: 364, 1985. Postia balsamea (Peck) Jülich, Persoonia 11:423, 1982.

Polyporus crispellus Peck, New York State Mus. Ann. Rep. 38: 91, 1885. Holotype: 'Osceola, Chas. H. Peck, Aug.', NYS (studied).

Tyromyces cutifractus Murrill, Mycologia 4: 94, 1912. Holotype: 'Oregon, Murrill 1064', NY (studied).

Basidiocarp pileate or effused-reflexed, pilei 2$5 \mathrm{~cm}$ wide, $5-10 \mathrm{~mm}$ thick at base, but mostly $4-6$ $\mathrm{mm}$, shelf-shaped or flabelliform, with broad or constricted attachment, single or imbricate, fairly tough when fresh, chalky hard when dry. Upper surface matt, at first cream coloured, but soon pale greyish brown and with soft darker zones, finally mouse grey; darkening when drying. Edge sharp, making a fairly regular arc. Pore surface cream coloured, when dry pale greyish brown or tan; pores angular or roundish, (3-)4-6 per mm; sterile margin bordering resupinate base narrow, matt, compact and well demarcated. Section: context cream coloured, leathery; when dry similar in colour but chalky brittle or hard; tubes with a little darker brownish tone, as if oily. Odour farinaceous or reminding non-perfumed soap; tasteless, not at all bitter or sour.
Monomitic, hyphae hyaline, with clamp connections, IKI- (a few specimens faintly amyloid), $\mathrm{CB}-$, almost unchanged in $\mathrm{KOH}$. Context hyphae interwoven or subparallel in a compact and tight fashion, (3.5-)3.9-6(-6.5) $\mu \mathrm{m}$ in diam., thick-walled to sclerified. Tube tramal hyphae (2.9-)3-4(-4.1) $\mu \mathrm{m}$, subparallel, thick-walled and glued-together; subhymenium indistinct. Hymenium with clavate basidia (14-)17-23 × (4.2-)4.6-5.3 $\mu \mathrm{m}$, short clavate basidioles $11-16 \times 4.4-5 \mu \mathrm{m}$; cystidia mostly infrequent, $12-20(-21) \times 4.2-5.5(-6) \mu \mathrm{m}, \mathrm{L}=19.72$ $\mu \mathrm{m}, \mathrm{W}=5.41 \mu \mathrm{m}, \mathrm{Q}=3.38-3.92(\mathrm{n}=11 / 3)$, obclavate or bullet-shaped, mostly terminal but also pleural cystidia seen, thick-walled and sometimes with minute apical encrustation; cystidia usually sunken rather deep in hymenium.

Spores short ellipsoid or almost truncate, thinwalled, IKI-, CB-, (3.4-)3.7-4.7(-5.3) $\times(2.1-) 2.2-$ 2.5(-2.8) $\mu \mathrm{m}, \mathrm{L}=4.03 \mu \mathrm{m}, \mathrm{W}=2.34 \mu \mathrm{m}, \mathrm{Q}=1.69-1.76$ $(n=90 / 3)$; spores often glued together in tetrads; apiculus almost invisible.

Specimens examined: Finland. Uusimaa. Helsinki, Kallio, Tokoinranta park, Crataegus douglasii, 3.IX.2001 Manninen, 4.X.2001 Manninen 1459; Koskela Hospital park, C. douglasii, 3.X.1999 Saarenoksa 01099, 6.X.1999 Niemelä 6669, 9.X.1999 Saarenoksa 01199,
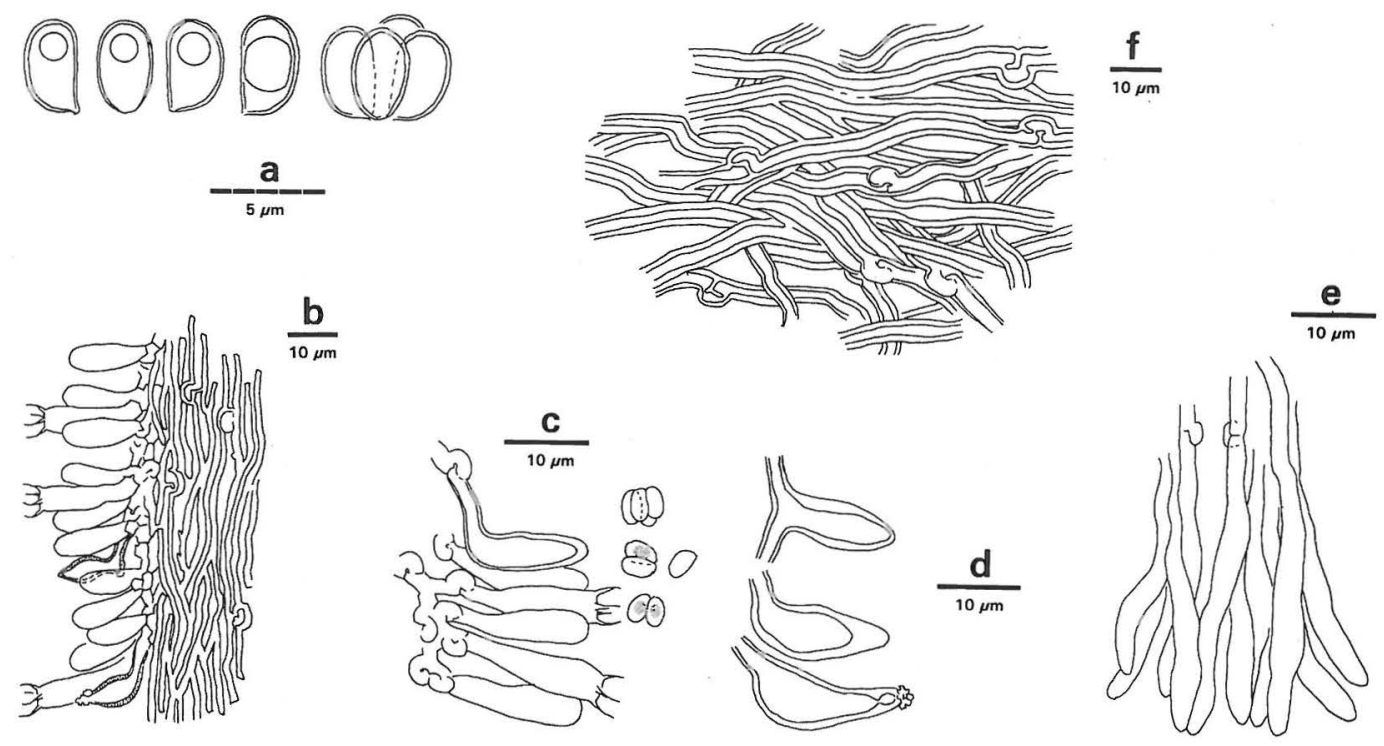

Fig. 4. Postia balsamea (Peck) Jülich. - a) Spores, b) hymenium and tube trama in vertical section, c) basidia, basidioles and cystidium, d) different types of cystidia, e) hyphae from dissepiment edge, f) thick-walled and tightly packed hyphae of context. Drawn in CB from 1973 Lohmeyer (c-e) and Saarenoksa 01099 (the others). 
7.IX.2000 Niemelä 6876; Rajatorppa, Betula, 28.VIII.1981 Erkkilä 231. Germany. Bavaria. Near Tittmonig by river Salzach, gymnosperm tree, 31.VII.1973 Lohmeyer. Switzerland. Jura Mts. Solothurn, P. abies, 30.X.1971 Schaeren. Czech Republic. Bohemia. Between Lidice and Stredokluky, W of Praha, Populus, 13.VIII.1973 Niemelä, Kotlaba \& Pouzar. U.S.A. New York. Adirondack Mts., on spruce [Abies balsamea], VIII.[1877] Peck (type of Polyporus balsameus, NYS); Lewis Co., Osceola, [Tsuga canadensis], VIII.[1884] Peck (type of Polyporus crispellus, NYS). Oregon. Newport, [Abies],13.XI.1911 Murrill 1064 (type of Tyromyces cutifractus, NY). China. Jilin. Antu, Baihe, Pinus, 15.IX.1995 Dai 2139.

\section{Notes on Postia balsamea}

Cystidia are often few and indistinct, usually submerged in the hymenium and not too thick-walled, even though they are unmistakable. Sometimes it took several sections to find them in a specimen. However, especially in some American specimens cystidia are numerous indeed, sometimes even dominating among hymenial elements, thickwalled and conspicuous. The type of Polyporus crispellus Peck belongs to the cystidiose kind, while in the type of Tyromyces cutifractus Murrill cystidia are rare and inconspicuous. The type of Polyporus balsameus Peck is intermediary in this respect. Spore sizes of these American type specimens agree completely with the measurements obtained from European materials (Table 1). The microscopy description above was compiled from European specimens only.

The species is very rare in Finland, and southern in its distribution. Erkkilä and Niemelä (1986) reported Postia balsamea from Helsinki, growing on Betula. However, it mostly lives on park trees, especially on old thick-stemmed Cratae- gus douglasii, which is native of western North America (Hämet-Ahti et al. 1992).

Postia balsamea was reported from Finland by Eriksson and Strid (1969) as Tyromyces kymatodes. That collection is preserved in GB and its duplicate is now in $\mathrm{H}$; according to our interpretation that northern material represents $P$. balsamina. In his thesis Norokorpi (1979) reported seven finds of Tyromyces kymatodes from buttrot columns of Picea abies in his research material from Perä-Pohjanmaa: Rovaniemi (Kivalo) and Kittilän Lappi: Kittilä and Meltaus, all of them in northern Finland. In that work T. kymatodes was isolated from older-than-average, living spruce trees with large butt-rot columns. Fungi were determined at least mostly from mycelia, and the identifications cannot be rechecked anymore. According to our results it is evident that $P$. balsamina was in question.

Kotlaba and Pouzar (1968) reviewed the Czech specimens of $P$. balsamea, and discussed the identity of Polyporus kymatodes Rostk., which was in Europe a widely used name for the taxon, until Pilát (1936-1942) showed the correct name to be Polyporus balsameus. The description of $P$. kymatodes by Rostkovius (1830) is vague, but many details (burning bitter taste, brown colours) rule out Postia balsamea, as pointed out by Kotlaba and Pouzar, who also showed that Leptoporus alma-atensis Pilát is a later synonym of $P$. balsamea. We did not restudy materials of these two taxa. Postia balsamea is rare in Bohemia, but a very wide range of hosts was listed of both gymnosperm and angiosperm trees.

Gilbertson and Ryvarden (1986-1987) report Polyporus basilaris Overh. (in Bailey 1941) to be synonymous with $P$. balsamea; indeed, the de-

Table 1. Postia balsamina sp. nova (bold face) and $P$. balsamea (light face): spore size in different herbarium materials. $\mathrm{L}=$ mean length, $\mathrm{W}=$ mean width, $\mathrm{Q}=$ length/width quotient, $\mathrm{n}=$ number of spores measured and number of specimens.

\begin{tabular}{lrrrrrr}
\hline & $\mathrm{L}$ & $\mathrm{W}$ & $\mathrm{Q}$ & $\mathrm{n}$ \\
\hline P. balsamina sp. nova: & $(\mathbf{4 . 1}-\mathbf{4}) \mathbf{3}-\mathbf{5 . 6}(-\mathbf{6 . 9}) \times(\mathbf{2 . 2 -}) \mathbf{2 . 3 - 2 . 9 ( - 3 . 1 )} \mu \mathrm{m}$ & $\mathbf{4 . 8 7} \mu \mathrm{m}$ & $\mathbf{2 . 6 2} \boldsymbol{\mu m}$ & $\mathbf{1 . 8 3}-\mathbf{1 . 9 2}$ & $\mathbf{1 5 0 / 5}$ \\
P. balsamea/Europe: & $(3.4-) 3.7-4.7(-5.3) \times(2.1-) 2.2-2.5(-2.8)$ & $\mu \mathrm{m}$ & $4.03 \mu \mathrm{m}$ & $2.34 \mu \mathrm{m}$ & $1.69-1.76$ & $90 / 3$ \\
Pol. balsameus type: & $3.6-4.4(-4.9) \times(2.1-) 2.2-2.4(-2.5)$ & $\mu \mathrm{m}$ & $4.04 \mu \mathrm{m}$ & $2.29 \mu \mathrm{m}$ & 1.76 & $30 / 1$ \\
Pol. crispellus type: & $(3.8-) 3.9-4.4(-4.8) \times(2.1-) 2.2-2.4(-2.6)$ & $\mu \mathrm{m}$ & $4.09 \mu \mathrm{m}$ & $2.28 \mu \mathrm{m}$ & 1.79 & $30 / 1$ \\
Tyr. cutifractus type: & $(3.6-) 3.8-4.3(-4.5) \times(2.1-) 2.2-2.4(-2.6)$ & $\mu \mathrm{m}$ & $3.99 \mu \mathrm{m}$ & $2.31 \mu \mathrm{m}$ & 1.73 & $30 / 1$ \\
\hline
\end{tabular}


scription (also in Overholts 1953) is clear and rules out our new species Postia balsamina. Still another reported synonym of $P$. balsamea, Tyromyces carbonarius Murrill is compatible with that species in mating tests (Gilbertson \& Ryvarden 1986-1987).

\section{Postia persicina Niemelä \& Y.C. Dai,} species nova

Figs. 5, 6

Carpophorum annuum, pileatum, firmum, colore pilei albo-persicinum vel pallide rosaceum; facies pororum album, in statu sicco olivaceocremeum; systema hypharum monomiticum, hyphae fibulatae; sine cystidiis; sporae cylindricae, 4.1-5 × 1.7-2.1 $\mu \mathrm{m}$.

Holotype: Finland. Kittilän Lappi. Kolari, Äkäslompolo, Varkaankuru, Picea abies, 17.VIII.1999 Niemelä 6453 \& Dai $(\mathrm{H})$.

Etymology: persicina (Lat., adj.), peach-coloured; referring to the pale reddish-orange upper surface.

Basidiocarp annual, pileate with obtuse margin, up to $7 \mathrm{~cm}$ wide, up to $1.5 \mathrm{~cm}$ thick at base, projecting $1.5 \mathrm{~cm}$ from substrate, broadly attached to wood, fleshy but fairly sturdy or somewhat tough when fresh, shrinking a little when drying; actively growing specimens exude milky droplets. Upper surface smooth or uneven but not rough, matt, pale peach coloured (pinkish orange) all over; no colour changes upon touch; the bright colour fades into tan or unevenly cream-andbrown when drying, and small (1-3 mm diam.) craters left from guttation droplets become visible. Edge sharp but not thin, entire, wavy. Pore surface white in fresh condition, even or swollen a little; pores (2-)3-5 per mm, regular, round or somewhat angular, glancing a little when tilted at incident light, tube orifices entire; when drying turning oily-looking olivaceous cream. Section: context soft, uniform, white, when dry chalky or in places resinous hard; tubes white when fresh, olivaceous cream when dry and translucent as if oily; tube layer up to $5 \mathrm{~mm}$. No specific smell, taste mild.

Monomitic, hyphae hyaline, with clamp connections, IKI variable, $\mathrm{CB}$-; in $\mathrm{KOH}$ some hyphae unchanged, others (especially in context) with swollen walls and then looking like skeletals, but all hyphae repeatedly clamped. Context hyphae (2.7-)3-5(-6.1) $\mu \mathrm{m}$ in diam. $(\mathrm{n}=30 / 1)$, IKI-, very thin-walled, delicate, subparallel and with prominent clamps; a few hyphae more thick-walled close to the attachment. Tube trama with very regular hyphae, (2.2-)2.9-4(-4.1) $\mu \mathrm{m}(\mathrm{n}=30 / 1)$, faintly grey (amyloid) in IKI, thin-walled, in a subparallel arrangement; dissepiment edge with wavy hyphal tips sometimes sparsely covered with small cubical crystals. Hymenium with clavate

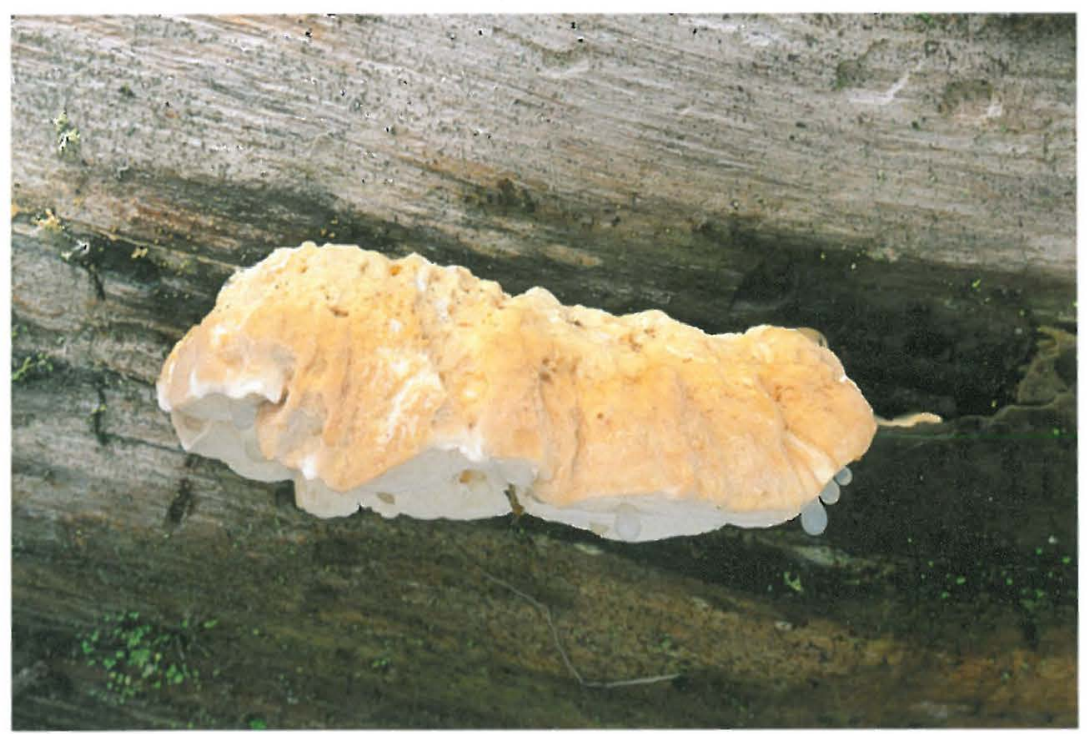

Fig. 5. Postia persicina Niemelä \& Y.C. Dai. Holotype, growing on fallen and decorticated trunk of spruce. Approximately in natural size. 
basidia, $15-20(-22) \times(4.4-) 4.8-5.9 \mu \mathrm{m}(\mathrm{n}=20 / 1)$, narrow clavate basidioles, $(10-) 11-16(-18) \times(3.4-)$ 3.9-5.1 $\mu \mathrm{m}(\mathrm{n}=20 / 1)$, and occasional hyphal pegs; no cystidia.

Spores cylindrical and slightly curved, thinwalled, IKI-, CB-, (3.8-)4.1-5(-5.3) × 1.7-2.1 $(-2.2) \mu \mathrm{m}, \mathrm{L}=4.47 \mu \mathrm{m}, \mathrm{W}=1.91 \mu \mathrm{m}, \mathrm{Q}=2.24-2.45$ $(n=60 / 2)$; often with a large, light-refracting guttule.

Specimens examined: Finland. Perä-Pohjanmaa. Rovaniemi, Pisavaara Strict Nat. Reserve, E slope of Sorvannulikka, Populus tremula, 29.VIII.1960 Eriksson 9525 \& Kujala (GB, herb. John Eriksson 4161; identification somewhat uncertain). Kittilän Lappi. Kolari, Äkäslompolo, Varkaankuru, Picea abies, 17.VIII.1999 Niemelä 6453 \& Dai (holotype). Russia. Karelian Rep. Kostomuksha, $2.5 \mathrm{~km}$ WSW of Venehlampi, P. abies, 2.IX.1998 Lindgren 11963 \& Siitonen.

\section{Notes on Postia persicina}

The reddish or orange tints of Postia persicina bring in mind Tyromyces kmetii (Bres.) Bondartsev \& Singer, which is a species of deciduous trees, and whose spores are thicker, up to $3 \mu \mathrm{m}$
(Kotiranta 1986). Also Postia guttulata (Peck) Jülich exudes abundant droplets if growing actively, but it has no reddish hues, it turns more clearly yellow when drying, and its shape is flat, flabelliform or shelf-shaped, with a constricted base.

The new species was found only once in its type locality; the trunk of spruce was checked again during four subsequent years (2000-2002, 2004), but no new basidiocarps emerged. That tree was large, partly decorticated, and it had fallen in a herb-rich slope with seeping water. The Russian find was collected from spruce, $16 \mathrm{~cm}$ thick at breast height. The tree trunk was still corticated (98\%) but bark was about to detach. The site was a swampy spruce forest, shadowy, about $75 \mathrm{~m}$ from a brook, i.e. outside the proximity of running water, evidently an old fire refuge. Host trees were still fairly hard wood both in the type locality and the Russian find. - We have no further notes on the find from Pisavaara, could not confirm the host, and hence its identification remains somewhat uncertain; it was not included in making the description.


Fig. 6. Postia persicina Niemelä \& Y.C. Dai, drawn in CB from holotype. a) Spores, b) basidia and basidioles, c) a section through dissepiment showing one hyphal peg arising from hymenium, d) the very thin-walled, often collapsed hyphae of the context, arranged in a spaced subparallel fashion. 


\section{Postia luteocaesia (A. David) Jülich}

Spongiporus luteocaesius A. David, Bull. Mens. Soc. Linnéenne Lyon 49:29, 1980.

Basidiocarps annual, pileate, semiorbicular or nodulose, 10-45 $\mathrm{mm}$ wide, 4-7 $\mathrm{mm}$ thick at base, soft when fresh, brittle when dry. Upper surface matt, a little rough (uneven), when young white with bright yellow outer border, when mature white all over, when old greyish at least at base, when dry sordid cream coloured. Edge entire, rounded and bright yellow in still-growing specimens, when mature sharp and white. Pore surface smooth, bright yellow (citric, vitelline or chrome yellow), bruised parts attaining vivid green tint within 1 hour; old specimens with greenish yellow underside; dried ones yellow, ochraceous yellow or greenish grey; pores round, (3-)4 per mm, in old basidiocarps merged together and then larger (12 per $\mathrm{mm}$ ), pore mouths minutely serrate or lacerate. Section: context soft, white, opaque; tubes greenish at base and yellow close to orifices, when fresh oily- or watery-looking. Odour weak, agreeable; taste faintly sour.

Monomitic, hyphae with clamp connections and somewhat thickened walls, regular, IKI-, CB-; in context (3.1-)3.4-4.8(-5.2) $\mu \mathrm{m}$ in diam., with spaced interwoven texture and often attached in bundles of 5-10 hyphae; in trama (1.6-)2-3.2 $(-3.4) \mu \mathrm{m}$, yellowish, interwoven (upper parts of tube trama) or subparallel (close to orifices); oil droplets common, small. No cystidia, no cystidioles. Spores cylindric and a little curved (allantoid), with slightly thickened wall which is pale grey in all media, looking like amyloid (in fact the greyish tint is natural of the spores), $\mathrm{CB}-$, (4.5-)4.7$6.3(-6.5) \times(1.5-) 1.6-1.9(-2) \mu \mathrm{m}, \mathrm{L}=5.34 \mu \mathrm{m}$, $\mathrm{W}=1.73 \mu \mathrm{m}, \mathrm{Q}=3.03-3.15(\mathrm{n}=60 / 2)$.

Specimens examined: Finland. Etelä-Savo. Valkeala, Repovesi Nat. Park, S lakeside of Valkjärvi, Pinus sylvestris, 16.IX.2004 Niemelä 7887, Kinnunen \& Schigel. France. Var. Ile de Port Cros, $10 \mathrm{~m}$ a.s.1., Pinus halepensis, 12.XII.1992 Rivoire 733 (ex herb. P. Rivoire, det. A. David 1992).

This species was described from France by David (1980). Its affinity to the Postia caesia (Schrad.: Fr.) P. Karst. complex was shown already then, and the identity as a separate species was confirmed with mating tests. Mme David sent a colour photograph of a fresh specimen to the author $\mathrm{TN}$, and our collection is strikingly similar. This species is known at least from France (David 1980, Ryvarden \& Gilbertson 1993-1994), Switzerland (Jaquenoud 1984), and Nepal (Hjortstam \& Ryvarden 1984). The French specimens were collected from pine (Pinus halepensis); the Nepalese one was growing on Abies.

The best specific characters are macroscopic. The bright yellow colour is not present in the other species of the Postia caesia complex. When the basidiocarps grow older, blue tones develop, characteristic of the complex, but mixing with yellow, they result in vivid moss-green in older tubes. Also bruised parts of young specimens attain green within an hour after collecting.

In the microscope $P$. luteocaesia is very similar to the other species of the $P$. caesia complex. Similarities are the monomitic structure with slightly thick-walled and regular hyphae, and very narrow, bluish-grey spores. Our measurements from French and Finnish specimens imply that David (1980) somewhat overestimated the thickness of the spores (" $5-5.5-6 \times 2 \mu \mathrm{m}$ "); her measurements were probably made in $\mathrm{KOH}$. Spore dimensions and ecology of $P$. caesia and $P$. alni Niemelä \& Vampola were published by Niemelä et al. (2001). Postia subcaesia (A. David) Jülich is a thicker, almost white member of the complex (David 1980, Ryvarden \& Gilbertson 1993-1994).

Acknowledgements: The Ministry of Environment of Finland is thanked for a generous research grant (YM131/ $5512 / 2002$ ), which enabled us to carry out studies in mycology. Staff persons of the Natural Heritage Services, Finnish Forest and Park Service, are thanked for invitations to study the nature reserves in question; in particular we owe our thanks to Päivi Paalamo and Heikki Eeronheimo (Rovaniemi: the Ylläs-Aakenus inventory), and Mari Nieminen (Savonlinna) and Paula Niskala (Jaala: Repovesi inventory) for their help and enthusiasm. Reima Saarenoksa and Olli Manninen (Helsinki) forwarded their finds of Postia balsamea, and Pekka Bader and Gudrun Norstedt (Umeå) sent collections of $P$. balsamina. Juha Siitonen (Helsinki) and Mariko Lindgren (Kuopio) allowed us to study and publish their Russian find of $P$. persicina. The curators of the herbaria NY, NYS, GB are thanked for loans of type and other important materials, and Pierre Rivoire (Orlienas) donated us a French specimen of Postia luteocaesia. Teuvo Ahti (Helsinki) kindly checked the Latin descriptions. 


\section{References}

Anonymous 1969: Flora of British fungi. Colour identification chart. - Royal Bot. Garden, Edinburgh. 6 unnumbered $\mathrm{pp}$.

Bailey, H.E. 1941: The biology of Polyporus basilaris. Bull. Torrey Bot. Club 68:112-120.

Bondartsev, A.S. 1953: Trutovye griby evropeyskoy chasti SSSR i Kavkaza. - Akad. Nauk SSSR, Moskva \& Leningrad. $1107 \mathrm{pp}$.

David, A. 1980: Étude du genre Tyromyces sensu lato: répartition dans les genres Leptoporus, Spongiporus et Tyromyces sensu stricto. - Bull. Mens. Soc. Linnéenne Lyon 49:6-56.

Eriksson, J. \& Strid, А. 1969: Studies in the Aphyllophorales (Basidiomycetes) of northern Finland. - Ann. Univ. Turku A II, Rep. Kevo Subarctic Sta. 4:112158.

Erkkilä, R. \& Niemelä, T. 1986: Polypores in the parks and forests of the City of Helsinki. - Karstenia 26:140.

Gilbertson, R.L. \& Ryvarden, L. 1986-1987: North American polypores 1-2. - Fungiflora, Oslo. 885 pp.

Hämet-Ahti, L., Palmén, A., Alanko, P. \& Tigerstedt, P.M.A. 1992: Suomen puu- ja pensaskasvio. Woody flora of Finland. - Dendrol. Seura, Helsinki. 373 pp.

Hansen, L. \& Knudsen, H. (eds.) 1997: Nordic macromycetes 3, heterobasidioid, aphyllophoroid and gastromycetoid Basidiomycetes. - Nordsvamp, Copenhagen. 444 pp.

Hjortstam, K. \& Ryvarden, L. 1984: Some new and noteworthy Basidiomycetes (Aphyllophorales) from $\mathrm{Ne}$ pal. - Mycotaxon 20:133-151.

Holmgren, P.K., Holmgren, N.H. \& Barnett, L.C. (eds.) 1990: Index herbariorum 1. The herbaria of the world. 8th ed. - New York Bot. Garden, Bronx. 693 pp.

Jaquenoud, M. 1984: Notules sur les porés 1. - Schweizerische Z. Pilzkunde 62:42-44.

Koivisto, A. (ed.) 2003: Ylläs-Aakenuksen alueen luonto. Nature in the Ylläs-Aakenus region. - Metsähallituksen Luonnonsuojelujulk. A 141:1-213.

Kotiranta, H. 1986: Skeletocutis lilacina and Tyromyces kmetii, two rare polypore species reported from Finland. - Windahlia 16:85-88.

Kotlaba, F. \& Pouzar, Z. 1968: Tyromyces balsameus (Peck) Murrill, bělochoroš cystidonosný v Čechách. - Česká Mykol. 22:121-128.
Niemelä, T. 2001a: Suomen kääpien määritysopas. Guide to the polypores of Finland. 13th ed. - Bot. Bull. Univ. Helsinki 179:1-142.

Niemelä, T. 2001 b: Trutovye griby Finlandii i prilegayushchey territorii Rossii. (Summary: Polypores of Finland and adjacent Russia.) - Norrlinia 8:1-120.

Niemelä, T. 2004: Suomen kääpien määritysopas. Guide to the polypores of Finland. 15th ed. - Bot. Bull. Univ. Helsinki 184:1-148.

Niemelä, T., Kinnunen, J., Lindgren, M., Manninen, O., Miettinen, O., Penttilä, R. \& Turunen, O. 2001: Novelties and records of poroid Basidiomycetes in Finland and adjacent Russia. - Karstenia 41:1-21.

Niemelä, T., Kinnunen, J. \& Renvall, P. \& Schigel, D. 2003: Phellodon secretus (Basidiomycota), a new hydnaceous fungus from northern pine woodlands. Karstenia 43:37-44.

Niemelä, T., Wallenius, T. \& Kotiranta, H. 2002: The kelo tree, a vanishing substrate of specified woodinhabiting fungi. - Polish Bot. J. 47:91-101.

Norokorpi, Y. 1979: Old Norway spruce stands, amount of decay and decay-causing microbes in northern Finland. - Communic. Inst. For. Fenniae 97(6):1-77.

Núñez, M. \& Ryvarden, L. 2001: East Asian polypores 2, Polyporaceae sensu lato. - Synopsis Fungorum 14:165-522.

Overholts, L.O. 1953: The Polyporaceae of the United States, Alaska, and Canada. - Univ. Michigan Press, Ann Arbor. 466 pp.

Petersen, J.H. 1996: Farvekort. - Foreningen til Svampekundskabens Fremme, Greve. 6 unnumbered pp.

Pilát, A. 1936-1942: Polyporaceae. - In: Kavina, C. \& Pilát, A. (eds.), Atlas des champignons de l'Europe 3. Privately published, Praha. 624 pp., 374 pls.

Rayner, R.W. 1970: A mycological colour chart. - Commonw. Mycol. Inst. \& British Mycol. Soc., Kew. 34 pp. \& 17 pls.

Rostkovius, F.W.T. 1830: Die Pilze Deutschlands. - In: Strurm, J. (ed.), Deutschlands Flora 3(10):37-68, pls. 17-32.

Ryvarden, L. \& Gilbertson, R.L. 1993-1994: European polypores 1-2. - Fungiflora, Oslo. 743 pp.

Schigel, D.S., Niemelä, T., Similä, M., Kinnunen, J. \& Manninen, O. 2004: Polypores and associated beetles of the North Karelian Biosphere Reserve, eastern Finland. - Karstenia 44: 00-00. 